\title{
Studies in 3,4-diaryl-1,2,5-oxadiazoles and their N-oxides: Search for better COX-2 inhibitors
}

MANGE RAM YADAV*

SHRIKANT T. SHIRUDE

DEVENDRA S. PUNTAMBEKAR

PINKAL J. PATEL

HETAL B. PRAJAPATI

ARVIND PARMAR

R. BALARAMAN

RAJANI GIRIDHAR

Pharmacy Department

Faculty of Technology and Engineering

Kalabhavan, The M. S. University

of Baroda, Vadodara-390 001, India
A series of 3,4-diaryl-1,2,5-oxadiazoles and 3,4-diaryl-1,2,5-oxadiazole $N$-oxides were prepared and evaluated for COX-2 and COX-1 binding affinity in vitro and for anti-inflammatory activity by the rat paw edema method. $p$ -Methoxy ( $p$-OMe) substituted compounds 9, 21, 34, 41, 42 showed COX-2 enzyme inhibition higher than that showed by compounds with other substituents. 3,4-Di(4-methoxyphenyl)-1,2,5-oxadiazole $N$-oxide (42) showed COX-2 enzyme inhibition of $54 \%$ at $22 \mu \mathrm{mol} \mathrm{L} \mathrm{L}^{-1}$ and COX-1 enzyme inhibition of $44 \%$ at $88 \mu \mathrm{mol} \mathrm{L}^{-1}$ concentrations, but showed very low in vivo anti-inflammatory activity. Its deoxygenated derivative (21) showed lower COX-2 enzyme inhibition $\left(26 \%\right.$ at $\left.22 \mu \mathrm{mol} \mathrm{L}{ }^{-1}\right)$ and higher COX-1 enzyme inhibition ( $53 \%$ at $\left.88 \mu \mathrm{mol} \mathrm{L} \mathrm{L}^{-1}\right)$ but, marked in vivo anti-inflammatory activity $\left(71 \%\right.$ at $\left.25 \mathrm{mg} \mathrm{kg}^{-1}\right)$ vs. celecoxib (48\% at $12.5 \mathrm{mg} \mathrm{kg}^{-1}$ ). Molecular modeling (docking) studies showed that the methoxy group is positioned in the vicinity of COX-2 secondary pocket and it also participates in hydrogen bonding interactions in the COX-2 active site. These preliminary studies suggest that $p$-methoxy ( $p$-OMe) group in one of benzene rings may give potentially active leads in this series of oxadiazole $/ N$-oxides.

Keywords: 1,2,5-oxadiazole, 1,2,5-oxadiazole N-oxide, COX-2 inhibitor

Discovery of two cyclooxygenase (COX) isoenzymes, a constitutive COX-1, serving as homeostatic prostanoid producing agent, and COX-2, responsible for pro-inflammatory prostanoid production, led to the development of new nonsteroidal anti-inflammatory drugs (NSAIDs), selective COX-2 inhibitors, promising minimal NSAID-typical toxicity with full anti-inflammatory efficacy. COX-2 inhibitors have been successful in treating inflammatory diseases like acute pain, rheumatoid arthritis and osteoarthritis; a few of them are also being studied for treating different types of cancer and Alzheimer's disease (1). Despite a few recent cautionary reports, the coxib treatment has a high degree of benefit over risk, and strategies for using NSAIDs have been described by Antman et al. (2).

*Correspondence, e-mail: mryadav11@yahoo.co.in 
A wide variety of carbocycles and heterocycles can serve as templates for COX-2 inhibitors, i.e., cyclopentene [SC-57666] (3) pyrazole [celecoxib (4), SC-58125 (5)], furan [rofecoxib (6)], isoxazole [valdecoxib (7), paracoxib sodium (8)], and pyridine [etoricoxib (9)]. In an ongoing research program in this department on COX-2 inhibitors with improved biological profile, we synthesized (10) a series of 3,4-diaryl-1,2,5-oxadiazoles and 3,4-diaryl-1,2,5-oxadiazole $N$-oxides. The compounds are novel in that the vicinal diaryl heterocyclic (five membered ring) pharmacophore of the coxibs has been incorporated with the nitric oxide releasing group (1,2,5-oxadiazole $\mathrm{N}$-oxide) into one single entity in the compounds synthesized. In this paper, we report the synthesis, preliminary biological evaluation and molecular docking studies of some of these oxadiazoles and their $\mathrm{N}$-oxides as selective COX-2 inhibitors.

1,2,5-oxadiazole $N$-oxides (furoxans) are reported (11) to be thiol dependent NO donors, whose biological activity is produced by action on the soluble guanylate cyclase-cyclic guanosine monophosphate (sGC-cGMP) pathway. Furoxans are considered to possess favorable bioactivity since they cause a slow release of $\mathrm{NO}$ resulting in longer duration of action without development of tolerance. Granik and Grigor (12) proposed the mechanism for the release of $\mathrm{NO}$ from 1,2,5-oxadiazole $\mathrm{N}$-oxides. It is also reported that release of NO from a nitric oxide donor drug produces beneficial effects such as reduction in blood pressure and prevention of atherosclerosis (11). NSAIDs possessing nitric oxide releasing capabilities are considered to be more promising drugs than the coxibs as these would be devoid of potential cardiovascular side effects associated with coxibs (11). Recently, a report has been published discussing the synthesis of some monosubstituted 3,4-diaryl-1,2,5-oxadiazoles (11) and N-oxides (35) as selective COX-2 inhibitors, expecting them to be free from adverse cardiovascular effects (13), but we claimed synthesis of these compounds much earlier (10).

\section{EXPERIMENTAL}

The yields reported here are un-optimized. Melting points were determined using a heating block-type melting point apparatus and are uncorrected. The IR spectra were recorded using the KBr disc method on an FT-IR model 8300 (Shimadzu, Japan). The ${ }^{1} \mathrm{H}$ $\mathrm{NMR}$ spectra on a $300 \mathrm{MHz}$ spectrometer (Brucker, USA) were recorded in $\mathrm{CDCl}_{3}$ (chemical shifts in $\delta$ ppm). Assignment of exchangeable protons $(\mathrm{NH})$ was confirmed by the $\mathrm{D}_{2} \mathrm{O}$ exchange. Selenium dioxide oxidations were carried out in an R-330F microwave oven (Sharp, Carousel, Thailand). Final compounds were purified by passing through a silica gel H (100-200 mesh, s. d. fine chemicals, India) purifying column using a mixture of ethyl acetate and petroleum ether or chloroform alone as eluents.

Synthetic pathway is presented in Schemes 1 and 2, and physicochemical and spectral data for the synthesized compounds are given in Tables I and II.

The starting compounds, 1,2-diaryl-1,2-ethanediones (2) (benzils), were prepared by two routes. The first route involved benzoin condensation followed by oxidation $(14,15)$ while the second involved Friedel-Crafts acylation followed by selenium dioxide oxidation (16).

Syntheses of 1,2-diaryl-1,2-ethanedione dioximes (3). General procedure. - A mixture of 1,2-diaryl-1,2-ethanediones (2) (benzils) $(10 \mathrm{mmol})$, hydroxylamine hydrochloride (60 


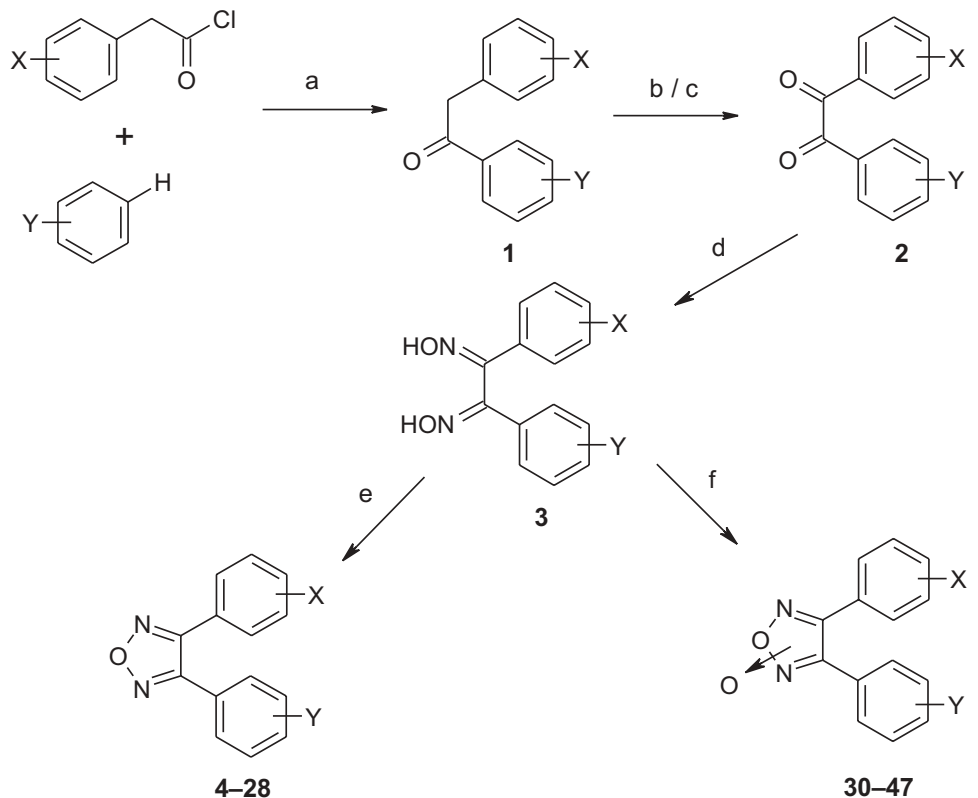

$\mathrm{X}=\mathrm{H}, 2-\mathrm{Cl}, 4-\mathrm{Cl}, 4-\mathrm{F}, 4-\mathrm{Me}, 4-\mathrm{OMe}, \mathrm{NO}_{2}$

$\mathrm{Y}=\mathrm{H}$, 4-Cl, 4-Br, 4-F, 4-Me, 4-OMe, 4-Sme, 4-SO $2 \mathrm{Me}$, 3,4-di-OMe

Reagents and conditions: $\mathrm{a}-\mathrm{AlCl}_{3}, \mathrm{CH}_{2} \mathrm{Cl}_{2}, 0-60{ }^{\circ} \mathrm{C}, 3-4 \mathrm{~h} ; \mathrm{b}-\mathrm{SeO}_{2}, \mathrm{Ac}_{2} \mathrm{O}$, reflux, 1-8 h; c - SeO , DMSO, microwave irradiation, 30-90 s; d - $\mathrm{NH}_{2} \mathrm{OH} \times \mathrm{HCl}, \mathrm{C}_{6} \mathrm{H}_{5} \mathrm{~N}$, reflux, 7-8 h; e $-\left(-\mathrm{CH}_{2} \mathrm{CO}\right)_{2} \mathrm{O}$, 180-5 ${ }^{\circ} \mathrm{C}, 10 \mathrm{~min} ; \mathrm{f}-$ aq. $\mathrm{NaOCl}(20 \%), 5-20^{\circ} \mathrm{C}, 14-16 \mathrm{~h}$

Scheme 1<smiles>COS(=O)(=O)c1ccc(-c2noc(C(C(Br)C(Br)Br)C(C)(C)C)n2)cc1</smiles>

Scheme 2

mmol) and pyridine $(10 \mathrm{~mL})$ was refluxed on an oil bath for $7 \mathrm{~h}$. The reaction mixture was poured onto crushed ice containing concentrated hydrochloric acid $(10 \mathrm{~mL})$. The precipitate obtained was filtered, washed with cold water and dried. The crude materials were used as such for the next step without further purification. 


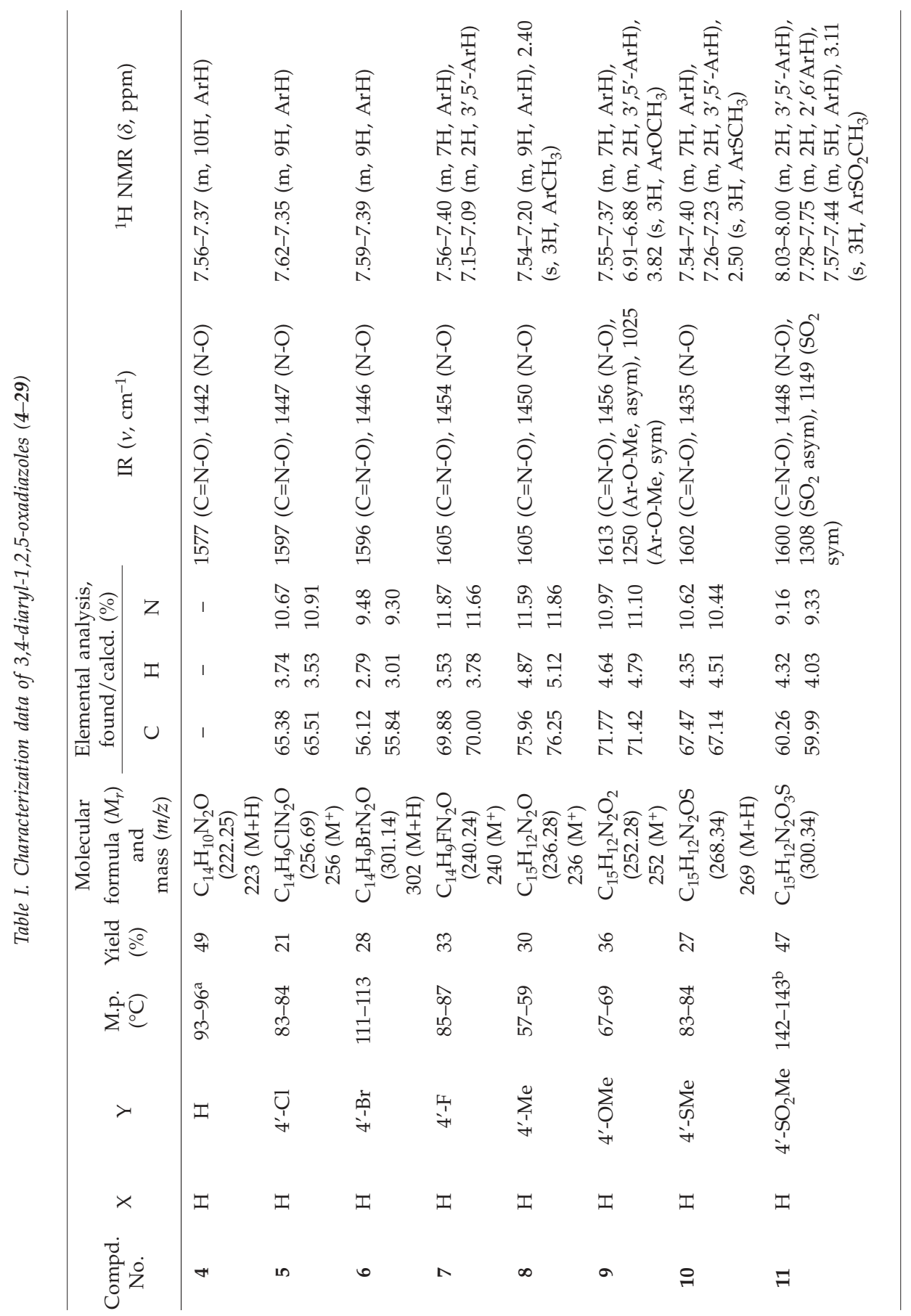




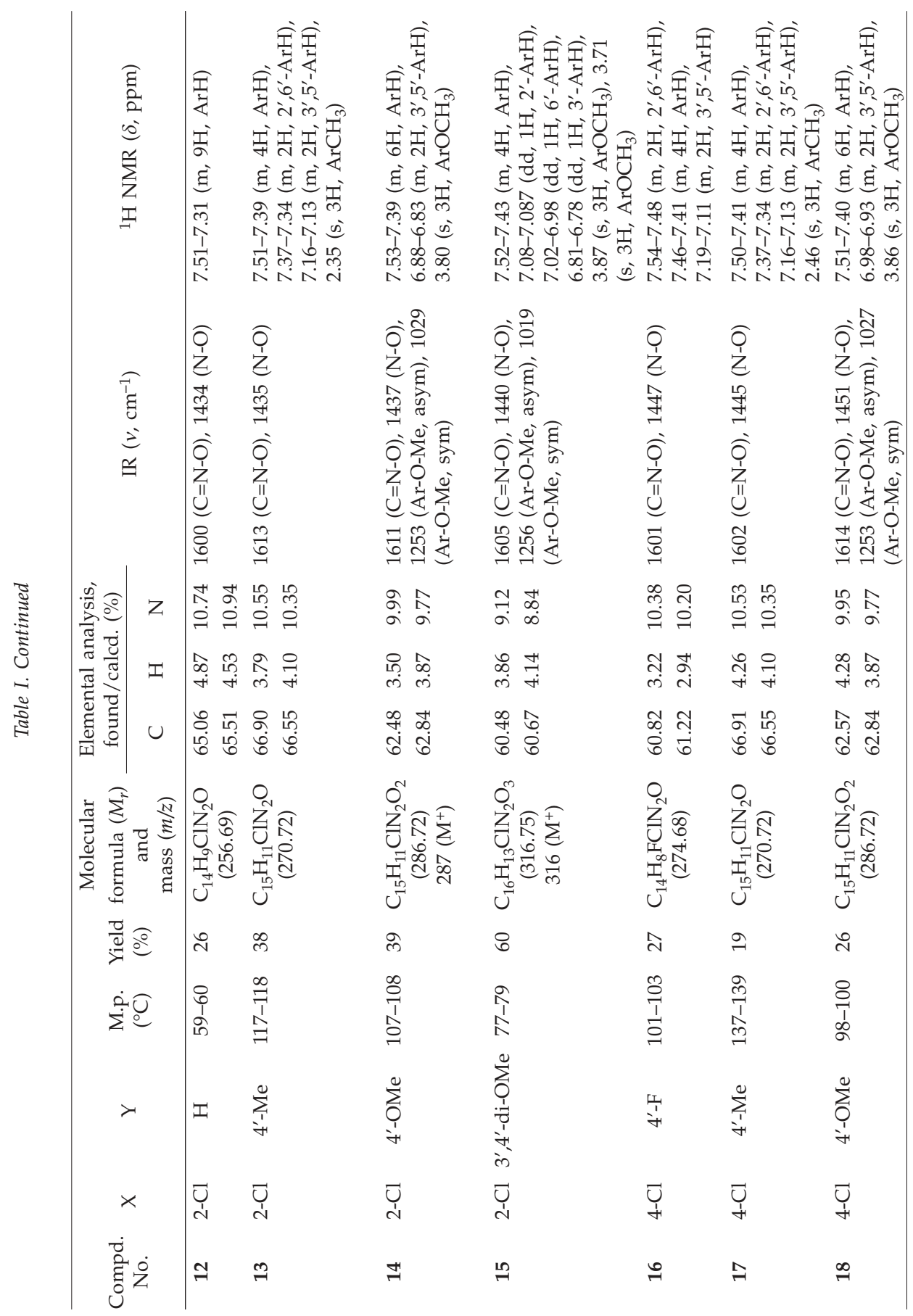




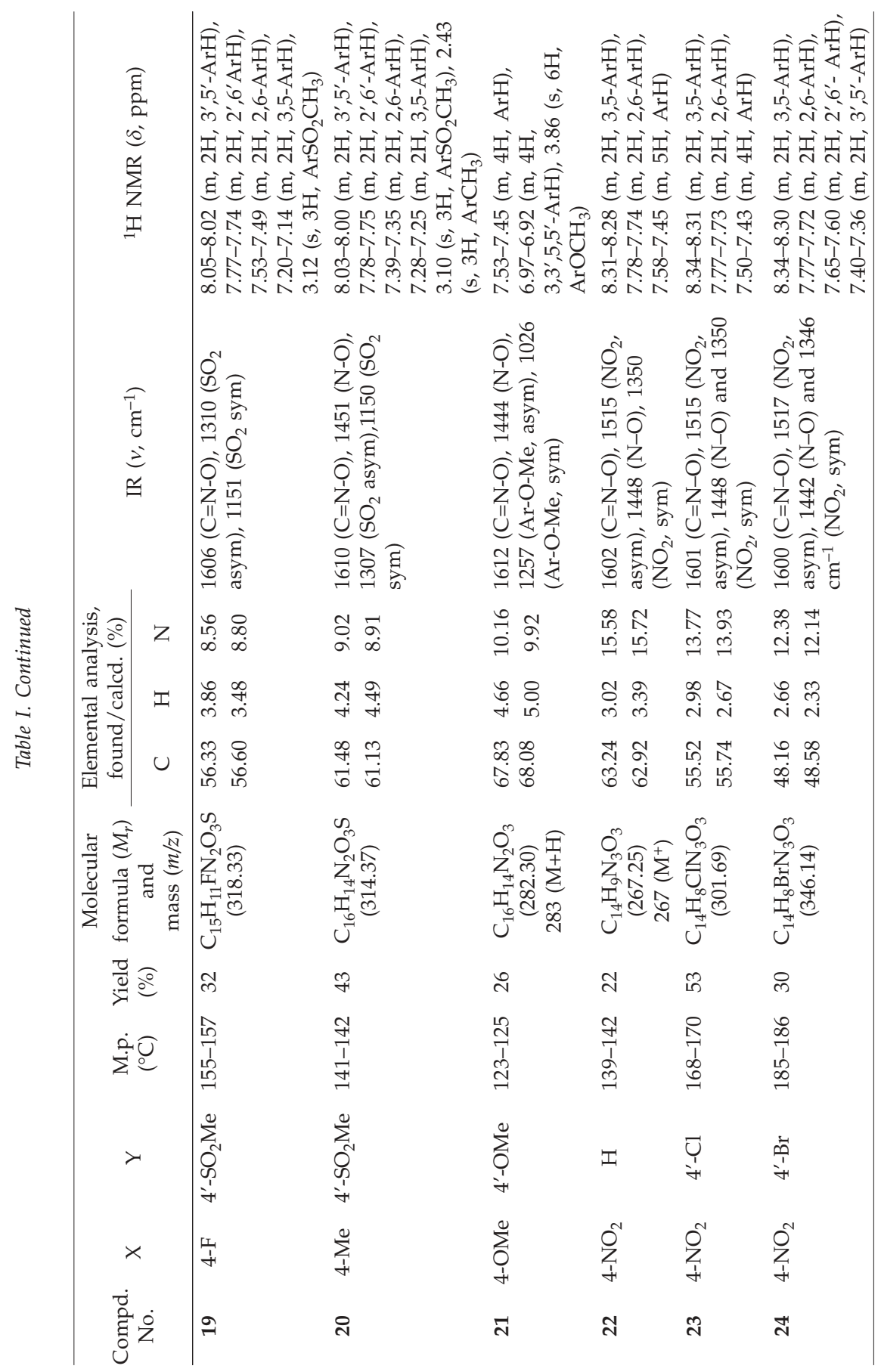




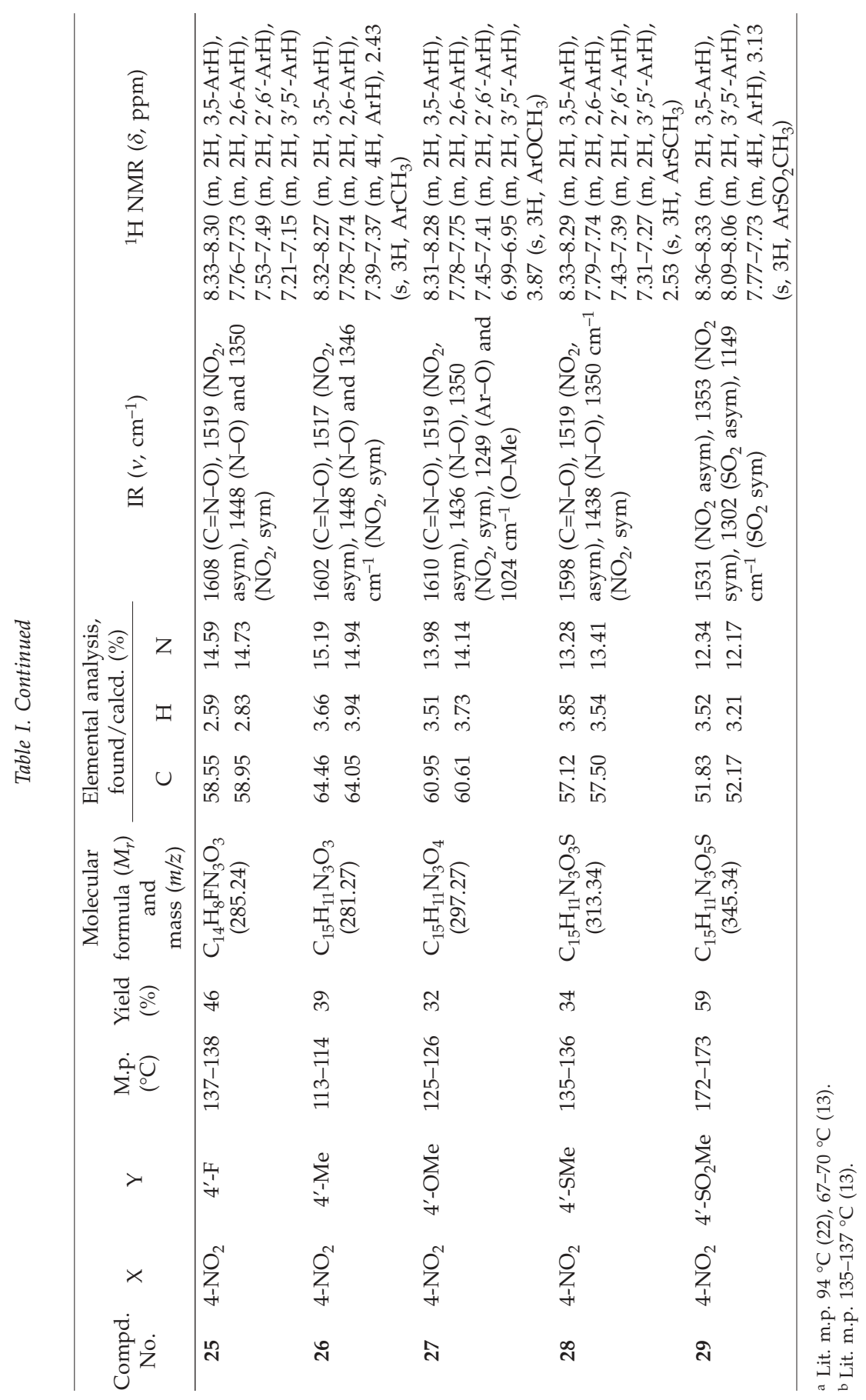




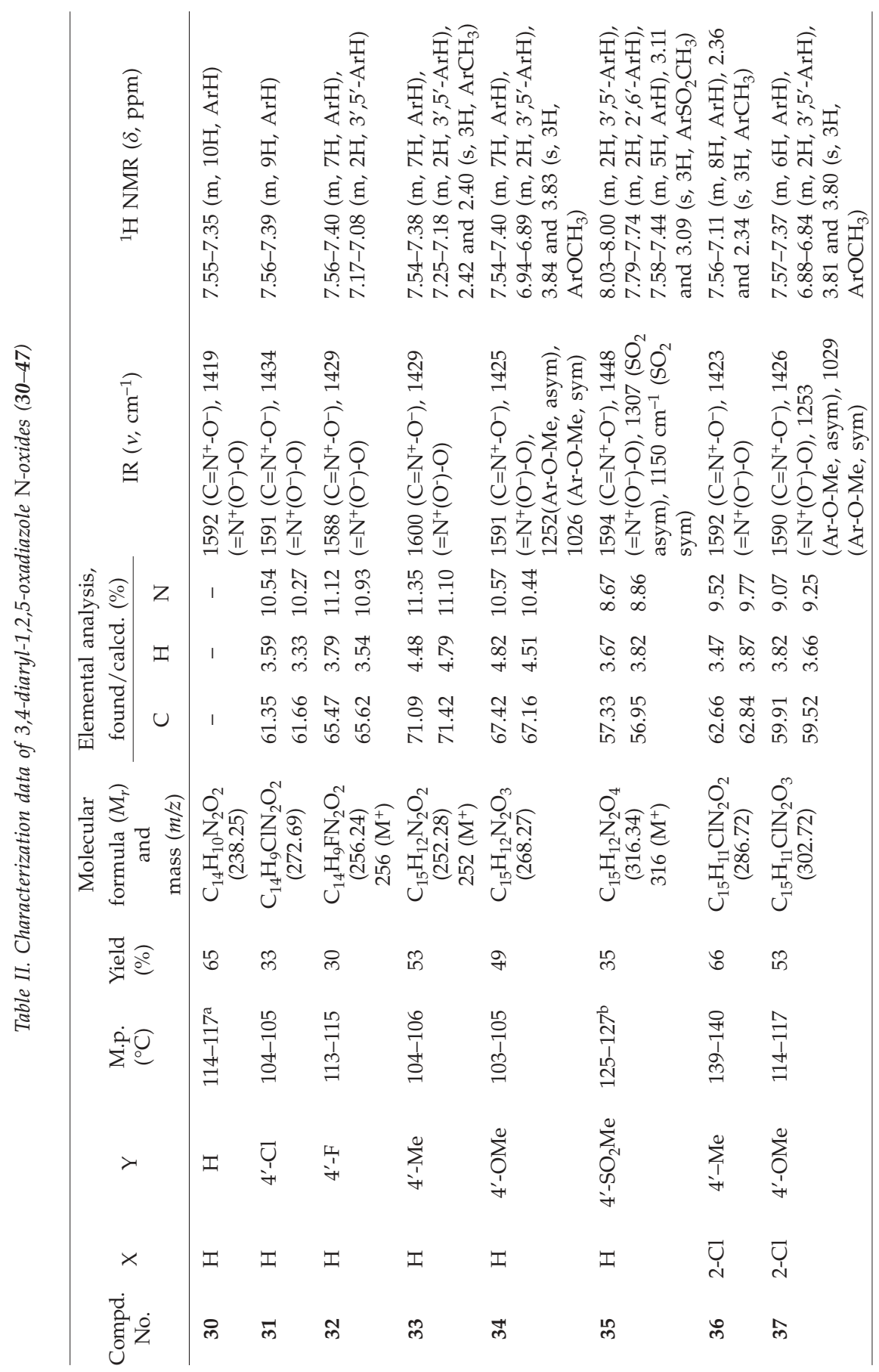




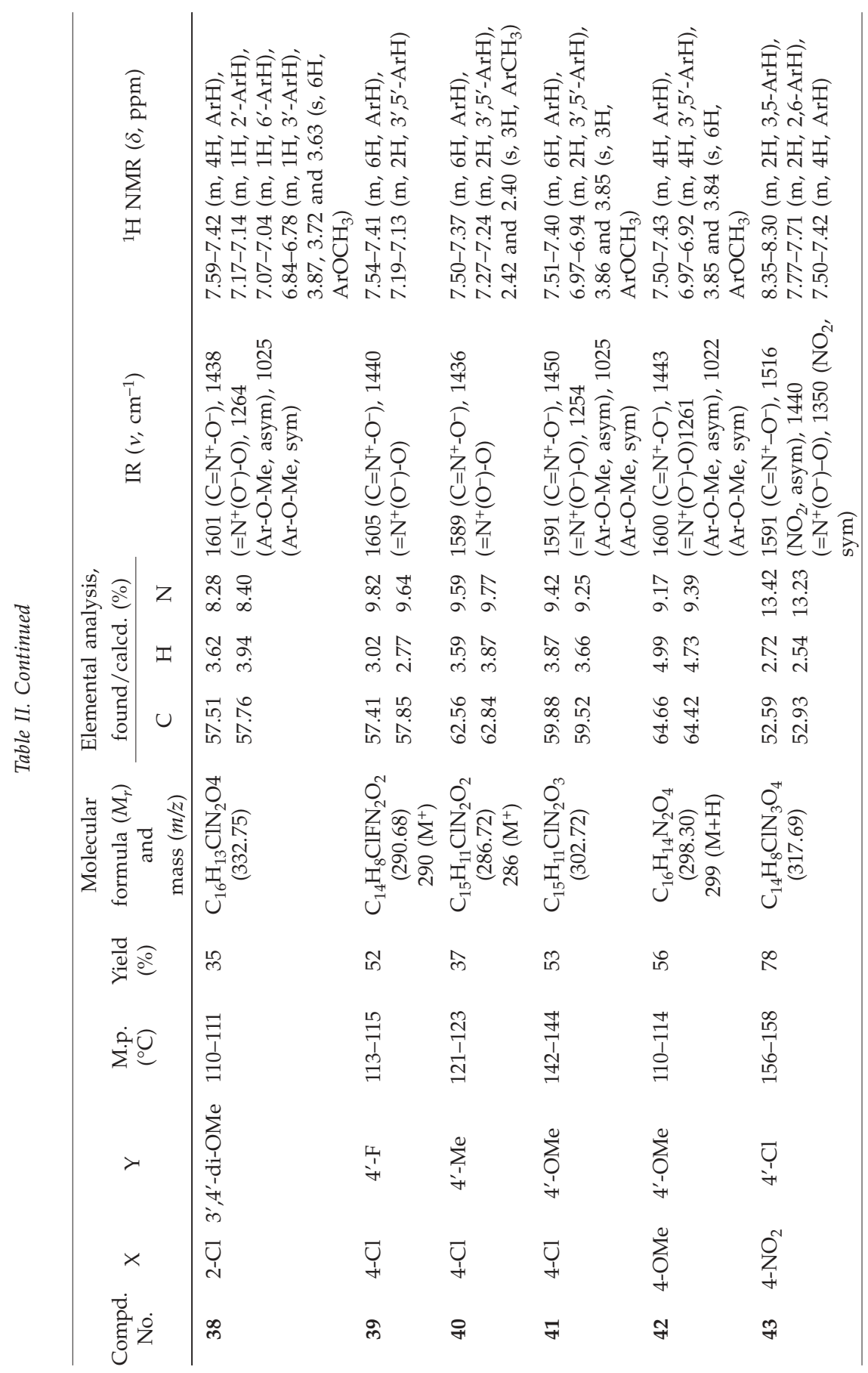




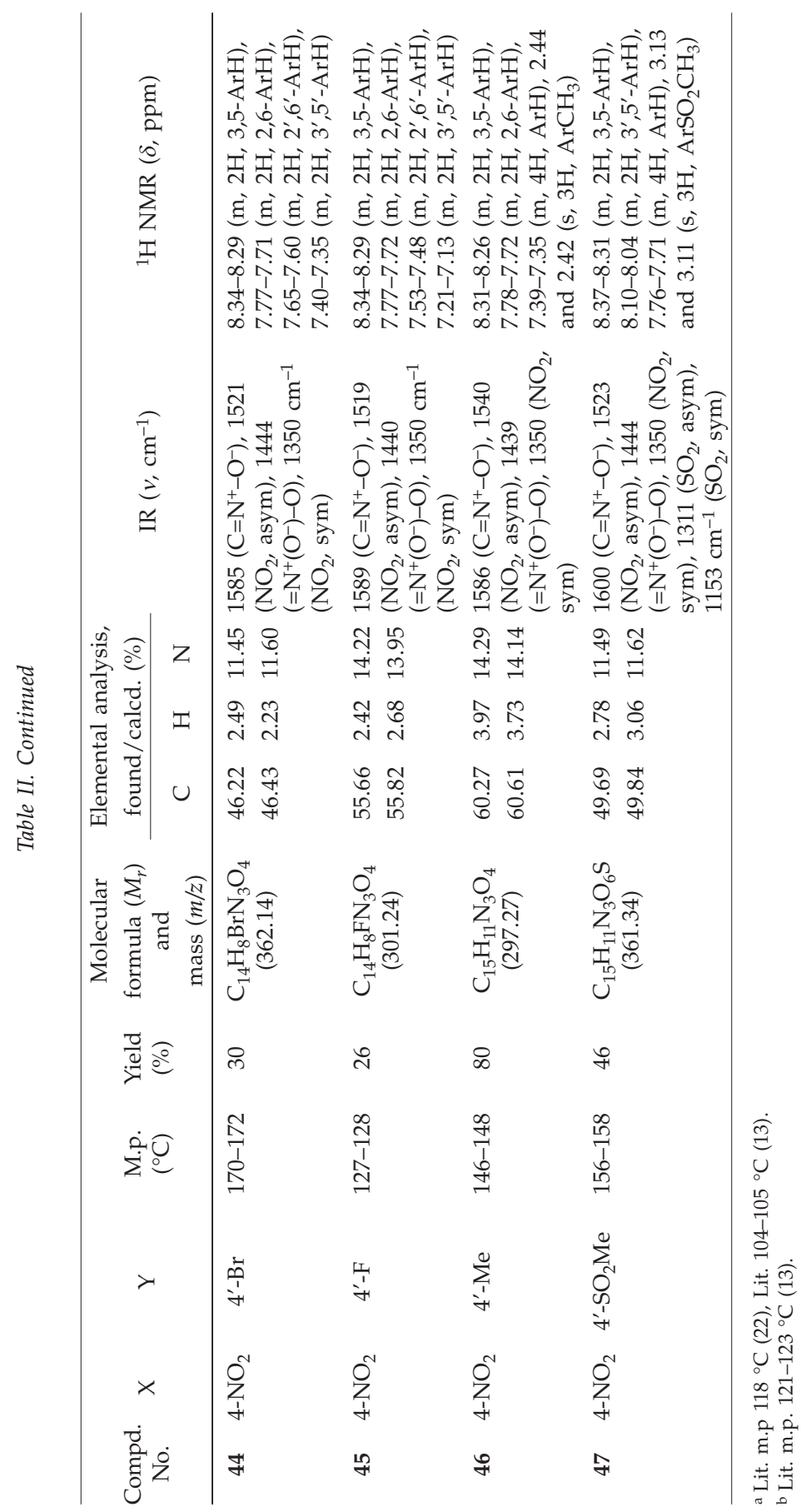


Syntheses of 3,4-diaryl-1,2,5-oxadiazoles (4-28). General procedure. - A mixture of 1,2-diaryl-1,2-ethanedione dioximes (3) $(4 \mathrm{mmol})$ and succinic anhydride $(20 \mathrm{mmol})$ was heated at $180-185{ }^{\circ} \mathrm{C}$ for $10 \mathrm{~min}$ in an oil-bath. The molten product was cooled, suspended in water and a sufficient quantity of sodium bicarbonate was added to neutralize the acid. The resulting mixture was extracted with successive quantities of chloroform $(3 \times 25 \mathrm{~mL})$. The combined organic extract was washed with water $(3 \times 50 \mathrm{~mL})$, dried and the solvent was recovered. The product obtained was crystallized from methanol to yield the title compounds.

Preparation of 3-(4-methylsulfonylphenyl)-4-(4-nitrophenyl)-1,2,5-oxadiazole (29). - To a cooled solution of $28(0.2 \mathrm{~g}, 0.64 \mathrm{mmol})$ in $\mathrm{CH}_{2} \mathrm{Cl}_{2}(20 \mathrm{~mL})$, m-chloroperbenzoic acid ( $m$-CPBA) $(1.0 \mathrm{~g}, 58 \mathrm{mmol}, 55-75 \%)$ was added under stirring. Stirring was continued at room temperature overnight. The reaction mixture was cooled to $0{ }^{\circ} \mathrm{C}$ and filtered at the pump to remove benzoic acid. Aqueous sodium metabisulphite $(20 \mathrm{~mL}, 10 \%, \mathrm{~m} / \mathrm{V})$ was added to the filtrate and stirred for $15 \mathrm{~min}$. The $\mathrm{CH}_{2} \mathrm{Cl}_{2}$ layer was separated and the aqueous layer was extracted with $\mathrm{CH}_{2} \mathrm{Cl}_{2}(3 \times 5 \mathrm{~mL})$. The combined organic extract was washed with aqueous sodium bicarbonate solution $(5 \%, 2 \times 10 \mathrm{~mL})$ followed by water $(3$ $\times 5 \mathrm{~mL}$ ). The $\mathrm{CH}_{2} \mathrm{Cl}_{2}$ layer was dried over anhydrous sodium sulphate and recovered. The resulting solid was crystallized from benzene to yield the title compound.

Syntheses of 3,4-diaryl-1,2,5-oxadiazole N-oxides (30-47). General procedure. - 1,2-Diaryl-1,2-ethanedione dioxime (3) (0.5 g) was dissolved in methanol $(10 \mathrm{~mL})$. A freshly prepared sodium hypochlorite solution $(10 \mathrm{~mL}, 20 \%)$ was added dropwise to the above solution at a temperature below $10{ }^{\circ} \mathrm{C}$ under stirring over a period of $30 \mathrm{~min}$ keeping the temperature below $10^{\circ} \mathrm{C}$. After complete addition, the reaction mixture was further stirred for $1 \mathrm{~h}$ at a temperature below $10^{\circ} \mathrm{C}$ and refrigerated overnight. The reaction mixture was poured onto crushed ice and the solid obtained was filtered and dried. Crystallization from methanol afforded the title compounds.

\section{In vitro $C O X$ inhibition assay}

The final compounds were evaluated for their ability to inhibit ovine COX-1 and COX-2 enzymes [percent inhibition at a fixed molar concentration $\left(\mu \mathrm{mol} \mathrm{L}{ }^{-1}\right)$ ] (17). Inhibition of the enzymes was determined with the colorimetric COX (ovine) inhibitor screening assay kit (Cayman Chemicals, USA) using ELISA reader following the procedure described in the catalog. The experiments were performed in duplicates.

\section{In vivo carrageenian induced rat paw edema assay}

Anti-inflammatory activity was determined by the carrageenian-induced rat paw edema method described by Winter et al. (18). Male Sprague-Dawley rats weighing 150 to $200 \mathrm{~g}$ (6-8 weeks old) were used in groups of six animals per group for the experiments. The animals were housed in a room with temperature of $22 \pm 2{ }^{\circ} \mathrm{C}$ under a $12 \mathrm{~h}$ light/dark cycle. They were allowed free access to food and water ad libitum. The protocol for the animal experiments performed was approved by the IAEC (Institute Animal Ethics Committee) registered under CPCSEA (Committee for the purpose of Control and Supervision of Experiments on Animals) Govt. of India. Compounds were administered orally as suspension in $1 \%$ carboxymethyl cellulose (CMC). Paw edema was induced by 
intradermal injection of $50 \mu \mathrm{L}$ of $1 \% \lambda$-carrageenian (Sigma, USA) into the subplantar region of the right hind paw, after one hour of compound administration. The paw volume was measured immediately after injection and after 3 hours using a plethysmometer (UGO-Basile, Italy). The control group received only the vehicle. Increase in paw volume was compared with that in the control group and percent inhibition was calculated taking the values in the control group as $0 \%$ inhibition.

\section{Molecular modeling (docking studies)}

All the molecular modeling studies reported herein were performed on a Silicon Graphics Fuel Workstation running on the IRIX 6.5 operating system using SYBYL 6.9 molecular modeling software from Tripos, Inc., USA (19) and GLIDE from Schrödinger Inc., USA (20). All compounds used for docking were built from the fragments in the SYBYL database. Each structure was fully geometry optimized using the standard Tripos force field (21) with a distance-dependent dielectric function until a root mean square deviation (rms) of $4.186 \mathrm{~J}^{-1}$ was achieved. Conformational search was carried out using MULTISEARCH option in SYBYL 6.9. The lowest energy conformer thus obtained was further minimized using the Tripos force field and was subsequently used in docking. The COX-2 receptor structure (pdb code: 6COX) obtained from the Protein Data Bank (USA) was refined to remove water molecules, adjust bond orders and formal charges prior to docking. Docking was performed using GLIDE software according to their previously reported protocol (20).

\section{RESULTS AND DISCUSSION}

\section{Chemistry}

The general method employed for the preparation of 3,4-diaryl-1,2,5-oxadiazoles (4-28) and 3,4-diaryl-1,2,5-oxadiazole $N$-oxides (30-47) and important intermediates 1-3 is illustrated in Scheme 1. Acid chlorides of phenylacetic acid and substituted phenylacetic acids were obtained by refluxing the acid with thionyl chloride or phosphorous trichloride. Excess of thionyl chloride or phosphorous trichloride was removed under vacuum and the resulting acid chlorides were used as such in Friedel-Crafts acylation reaction with benzene and monosubstituted benzenes to yield 1,2-diaryl-1-ethanones (1) (16). IR spectra of these ethanones showed the presence of characteristic carbonyl stretching peaks at $1690-1665 \mathrm{~cm}^{-1}$. Their ${ }^{1} \mathrm{H}$ NMR spectra showed characteristic signals for $-\mathrm{CH}_{2}-$ at about $\delta 4.37 \mathrm{ppm}$.

1,2-Diaryl-1,2-ethanediones 2 (benzils) were synthesized by selenium dioxide $\left(\mathrm{SeO}_{2}\right)$ oxidation of 1 using $\mathrm{AcOH} / \mathrm{Ac}_{2} \mathrm{O}$ as solvents at refluxing temperatures up to $8 \mathrm{~h}$. The reaction was completed under these conditions except for nitro substituted derivatives of $\mathbf{1}$. Therefore, a new method was developed (16) for the oxidation of 1,2-diaryl-1-ethanones 1, which proved to be faster and more efficient. In this method, the reaction was carried out in DMSO in a microwave oven for $30 \mathrm{~s}$ to afford the desired diones 2 in almost pure form. ${ }^{1} \mathrm{H}$ NMR spectra of these diones 2 showed the absence of characteristic signals for $-\mathrm{CH}_{2}$ - at $\delta 4.37 \mathrm{ppm}$. Some of benzils 2 were prepared by benzoin/cross ben- 
zoin condensation followed by oxidation, as per the reported procedures (14, 15). 1,2-Diphenyl-1,2-ethanedione (benzil), 1,2-di(4-methoxyphenyl)-1,2-ethanedione (anisil), 1-(2chlorophenyl)-2-(4-methoxyphenyl)-1,2-ethanedione and 1-(2-chlorophenyl)-2-(3,4-dimethoxyphenyl)-1,2-ethanedione were prepared by this method $(14,15)$.

Benzils 2 were oximated into the corresponding 1,2-diaryl-1,2-ethanedione dioximes 3 using the hydroxylamine hydrochloride/pyridine system at refluxing temperatures. Most of the dioximes were isolated as solid compounds. Their TLC showed two spots and IR spectra indicated the absence of keto stretching bands. Since there is a possibility of formation of $s y n$ and anti products, no efforts were made to isolate these geometric isomers and the dioximes 3 were used as such for the next step.

Cyclization of 3 to 3,4-diaryl-1,2,5-oxadiazoles was attempted using different aci$\mathrm{dic} /$ basic dehydrating agents but could only be effected by heating with succinic anhydride at $180-185{ }^{\circ} \mathrm{C}$. Oxidation of 3 was carried out with aqueous sodium hypochlorite solution (20\%) to obtain 3,4-diaryl-1,2,5-oxadiazole $N$-oxides. It was observed that methylsulfanyl (-SMe) also got oxidized to methylsulfonyl $\left(-\mathrm{SO}_{2} \mathrm{Me}\right)$ during sodium hypochlorite treatment of compound 47 . This was confirmed by the shift of methyl signal from $\delta 2.50$ to $\delta 3.11 \mathrm{ppm}$ in its ${ }^{1} \mathrm{H} \mathrm{NMR}$ spectrum. Conversion of $-\mathrm{SMe}$ to $-\mathrm{SO}_{2} \mathrm{Me}$ was also performed with $m$-CPBA either at 1,2-diaryl-1-ethanone 1 or at 3,4-diaryl-1,2,5-oxadiazole stages (Scheme 2). The elemental and spectral data of the synthesized compounds are given in Tables I and II.

\section{Biological and molecular modeling studies}

All compounds described herein were evaluated in vitro for COX-2 binding affinity at a concentration of $22 \mu \mathrm{mol} \mathrm{L}-1$ by the colorimetric COX (ovine) inhibitor screening assay. Selected active compounds were also evaluated for COX-1 binding affinity at a higher concentration $\left(88 \mu \mathrm{mol} \mathrm{L}^{-1}\right)$ (Table III). Compounds that showed promising COX-2 inhibitory activity were further screened for their anti-inflammatory activity (Table IV) in vivo using the carrageenian induced rat paw edema method.

Amongst all the compounds, methoxy (-OMe) substituted compounds 9, 21, 34, 41, 42 showed COX-2 enzyme inhibition higher than that shown by compounds with other substituents. 3,4-Di(4-methoxyphenyl)-1,2,5-oxadiazole $\mathrm{N}$-oxide (42) showed COX-2 enzyme inhibition of $54 \%$ at $22 \mu \mathrm{mol} \mathrm{L}-1$ and COX-1 enzyme inhibition of $44 \%$ at $88 \mu \mathrm{mol}$ $\mathrm{L}^{-1}$ concentration, but showed mild in vivo anti-inflammatory activity at a $25 \mathrm{mg} \mathrm{kg}-1$ dose. However, its deoxygenated analog 21 showed lower COX-2 enzyme inhibition (26\% at $\left.22 \mu \mathrm{mol} \mathrm{L}^{-1}\right)$ and higher COX-1 enzyme inhibition $(53 \%$ at $88 \mu \mathrm{mol} \mathrm{L}-1)$, but showed stronger in vivo anti-inflammatory activity at a $25 \mathrm{mg} \mathrm{kg}^{-1}$ dose (71\%) than standard celecoxib at $12.5 \mathrm{mg} \mathrm{kg}^{-1}(48 \%)$. However, at the same dose level of $12.5 \mathrm{mg} \mathrm{kg}^{-1}$, it showed much lower activity than (21\%) celecoxib. This preliminary study suggests that the methoxy (-OMe) group at 4-position of one of the phenyl rings may be a suitable pharmacophore for COX-2 enzyme binding in this series of compounds. Replacement of one of the -OMe groups of compound 21 by an electron withdrawing $-\mathrm{NO}_{2}$ group resulted in a complete loss of COX-2 enzyme affinity. Compounds 11, 19, 20, 29 and 47 with the well known COX-2 enzyme pharmacophore (methylsulfonyl, $-\mathrm{SO}_{2} \mathrm{Me}$ ) failed to show COX-2 enzyme inhibition at a $22 \mu \mathrm{mol} \mathrm{L}^{-1}$ concentration, but compound 11 exhibited in vivo anti-inflammatory activity at $25 \mathrm{mg} \mathrm{kg}^{-1}$ comparable to celecoxib at $12.5 \mathrm{mg}$ $\mathrm{kg}^{-1}$. Compound 21 was found to be the most active compound in the series. 
Table III. In vitro COX-2 inhibition data for 3,4-diaryl-1,2,5-oxadiazoles and 3,4-diaryl-1,2,5-oxadiazole N-oxides (4-47)a

\begin{tabular}{|c|c|c|}
\hline \multirow{2}{*}{$\begin{array}{l}\text { Compd. } \\
\text { No. }\end{array}$} & \multicolumn{2}{|c|}{ Inhibition $^{\mathrm{b}}(\%)$} \\
\hline & $\begin{array}{c}\text { COX-2 } \\
\left(22 \mu \mathrm{mol} \mathrm{L}^{-1}\right)\end{array}$ & $\begin{array}{c}\text { COX-1 } \\
\left(88 \mu \mathrm{mol} \mathrm{L}^{-1}\right)\end{array}$ \\
\hline 4 & 5 & - \\
\hline 8 & 8 & - \\
\hline 9 & 17 & - \\
\hline 10 & 5 & - \\
\hline 14 & 9 & - \\
\hline 15 & 5 & - \\
\hline 18 & 4 & - \\
\hline 19 & 4 & - \\
\hline 21 & 26 & 53 \\
\hline 23 & 4 & - \\
\hline 25 & 7 & - \\
\hline 32 & 3 & - \\
\hline 34 & 21 & 55 \\
\hline 35 & 11 & - \\
\hline 37 & 6 & - \\
\hline 38 & 4 & - \\
\hline 41 & 20 & 53 \\
\hline 42 & 54 & 45 \\
\hline 45 & 2 & - \\
\hline 42 & 54 & 45 \\
\hline Celecoxib & 95 & - \\
\hline
\end{tabular}

a Compounds 5-7, 11-13, 16, 17, 20, 22, 24, 26-31, 33, 36, 39, 40, 43, 44, 46 and 47 were found to be inactive at the concentration of $22 \mu \mathrm{mol} \mathrm{L}-1$.

- Not evaluated.

b Experiments were performed in duplicate.

All the synthesized compounds were energy minimized and docked in the active site of COX-2, but only a few binding interactions are discussed here. The binding interaction of 3,4-di(4-methoxyphenyl)-1,2,5-oxadiazole (21, 26\% COX-2 inhibitory activity) was studied within the COX-2 binding site by molecular docking studies. The para methoxy group is oriented in the vicinity of COX-2 secondary pocket (Phe ${ }^{518}$, $\mathrm{Arg}^{513}$, Gln ${ }^{192}, \mathrm{Val}^{523}$, Ser ${ }^{353}$ ) as shown in Fig. 1. The oxygen atom of the para substituted methoxy group to the C-3 phenyl ring is hydrogen bonded with the backbone $\mathrm{NH}$ of $\mathrm{Ile}^{517}$ (distance $=4.1 \AA$ ). The oxygen atom of the other methoxy group that is para substituted to C-4 phenyl ring also forms a hydrogen bond with $\mathrm{OH}$ of $\operatorname{Tyr}^{348}$ (distance $=4.9 \AA$ ). The $\mathrm{N}^{2}$-atom of the central oxadiazole ring forms a favorable hydrogen bond with $\mathrm{NH}_{2}$ of $\operatorname{Arg}^{120}($ distance $=3.65 \AA)$. 
Table IV. In vivo anti-inflammatory data for selected compounds

\begin{tabular}{ccc}
\hline Compd. No. & Dose $\left(\mathrm{mg} \mathrm{kg}^{-1}\right)$ & $\begin{array}{c}\text { Paw volume }(\mathrm{mL}) \\
(\% \text { inhibition })^{\mathrm{a}}\end{array}$ \\
\hline Control & 25 & $0.820 \pm 0.02(0)$ \\
$\mathbf{1 1}$ & 25 & $0.28 \pm 0.06(53)$ \\
$\mathbf{2 0}$ & 25 & $0.57 \pm 0.10(35)$ \\
$\mathbf{2 1}$ & 25 & $0.16 \pm 0.04(71)$ \\
$\mathbf{4 1}$ & 25 & $0.25 \pm 0.03(31)$ \\
$\mathbf{4 2}$ & 25 & $0.04 \pm 0.01(5)$ \\
$\mathbf{2 1}$ & 12.5 & $0.16 \pm 0.04(21)$ \\
Celecoxib & 12.5 & $0.39 \pm 0.05(48)$ \\
\hline
\end{tabular}

${ }^{\text {a }}$ Mean $\pm \mathrm{SD}, n=6$.

Binding mode of 3,4-di(4-methoxyphenyl)-1,2,5-oxadiazole $\mathrm{N}$-oxide (42, 54\% COX-2 inhibitory activity) was also examined (Fig. 2). As observed in other compounds, also here the $p$-methoxy group is oriented towards the secondary pocket of the enzyme, which is similar to the orientation of $-\mathrm{SO}_{2} \mathrm{NH}_{2}$ in celecoxib. The central oxygen atom of the oxadiazole ring participates in hydrogen bond formation with $\mathrm{NH}_{2}$ of $\mathrm{Arg}^{120}$ (distance = $2.57 \AA$ ). Oxygen atom of $\mathrm{N}$-oxide forms a favorable hydrogen bond with $\mathrm{NH}$ of Leu ${ }^{531}$. The methoxy group substituted on the C-3 phenyl ring forms a hydrogen bond with $\operatorname{Tyr}^{348}$ (distance $=4.8 \AA$ ). The methoxy group on the C-4 phenyl ring also participates in the formation of the hydrogen bond with backbone NH of Ile ${ }^{517}$ (distance $=3.83 \AA$ ) and $\mathrm{NH}$ of $\operatorname{Gln}^{192}$ (distance $=4.8 \AA$ ). Amongst all the compounds in the series, 42 had the lowest intermolecular energy of $-3.5 \times 10^{5} \mathrm{~J} \mathrm{~mol}^{-1}$, indicating its stability in the COX-2 active site.
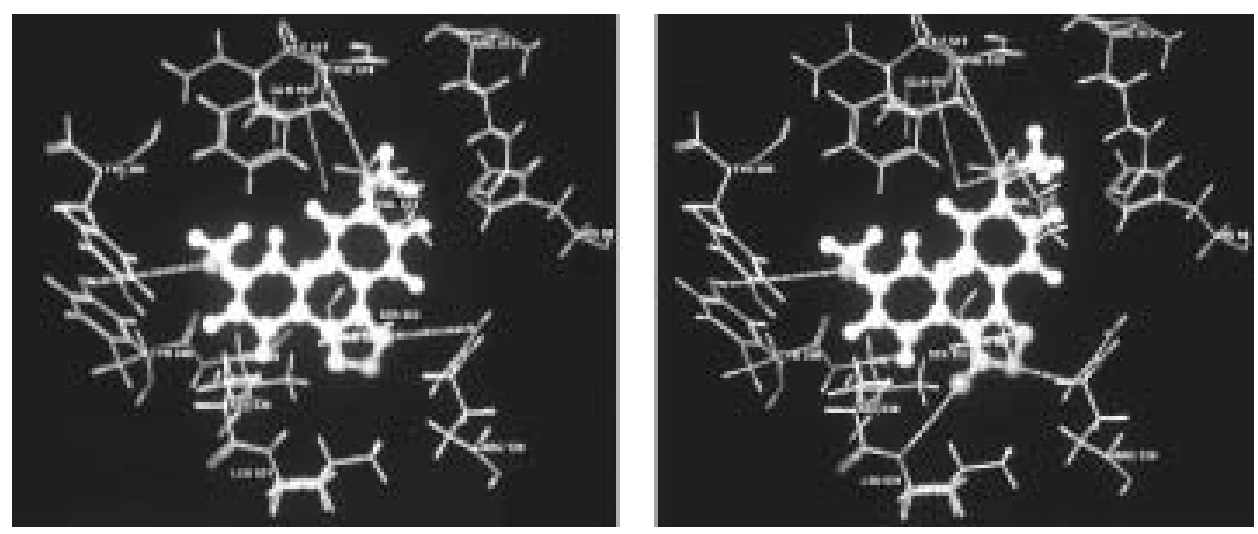

Fig. 1. Docking of compounds (ball and stick) in the active site of murine COX-2: a) 3,4-di(4-methoxyphenyl)-1,2,5-oxadiazole (21) and b) 3,4-di(4-methoxyphenyl)-1,2,5-oxadiazole $N$-oxide (42). 


\section{CONCLUSIONS}

Docking studies of 3,4-diaryl-1,2,5-oxadiazoles and 3,4-diaryl-1,2,5-oxadiazole $\mathrm{N}$-oxides indicate a favorable orientation of the methoxy group in the COX-2 active site. Lower binding energies also indicate the stability of 3,4-diaryl-1,2,5-oxadiazoles and their $\mathrm{N}$-oxides in the active site. This supports in vitro and in vivo anti-inflammatory data. These preliminary studies suggest that the methoxy group may be acting as a pharmacophore for the COX-2 enzyme binding site in series of 1,2,5-oxadiazoles and their $N$-oxides. Further work in this direction is in progress.

Acknowledgements. - Authors are grateful to the University Grant Commission (UGC), New Delhi, for the grant of a major research project and Senior Research Fellowship (SRF) to H. B. P., and to the All India Council for Technical Education (AICTE) for the award of National Doctoral Fellowship (NDF) to S. T. S.

\section{REFERENCES}

1. T. D. Warner and J. A. Mitchell, Cyclooxygenases: new forms, new inhibitors, and lessons from the clinic, FASEB J. 18 (2004) 790-804.

2. E. M. Antman, D. DeMets and J. Loscalzo, Cyclooxygenase inhibition and cardiovascular risk, Circulation 112 (2005) 759-770.

3. J. J. Li, G. D. Anderson, E. G. Burton, J. N. Cogburn, J. T. Collins, D. J. Garland, S. A. Gregory, H. C. Huang, P. C. Isakson, C. M. Koboldt, E. W. Logusch, M. B. Norton, W. E. Perkins, E. J. Reinhard, K. Seibert, A. W. Veenhuizen, Y. Zhang and D. B. Reitz, 1,2-Diarylcyclopentenes as selective cyclooxygenase-2 inhibitors and orally active anti-inflammatory agents, J. Med. Chem. 38 (1995) 4570-4578.

4. T. D. Penning, J. J. Talley, S. R. Bertenshaw, J. S. Carter, P. W. Collins, S. Docter, M. J. Graneto, F. J. Lee, J. W. Malecha, J. M. Miyashiro, R. S. Rogers, D. J. Rogier, S. S. Yu, G. A. Anderson, F. G. Burton, J. N. Cogburn, S. A. Gragory, C. M. Koboldt, W. E. Perkins, K. Seibert, A. W. Veenhuizen, Y. Y. Zhang and P. C. Isakson, Synthesis and biological evaluation of the 1,5-diarylpyrazole class of cyclooxygenase-2 inhibitors: Identification of 4-[5-(4-methylphenyl)-3-(trifluoromethyl) -1H-pyrazol-1-yl]benzenesulfonamide (SC-58635, Celecoxib), J. Med. Chem. 40 (1997) 1347-1365.

5. G. Dannhardt and W. Kiefer, Cyclooxygenase inhibitors - current status and future prospects, Eur. J. Med. Chem. 36 (2001) 109-126.

6. P. Prasit, Z. Wang, C. Brideau, C. C. Chan, S. Charleson, W. Cromlish, D. Either, J. F. Evans, A. W. Ford-Hutchinson, J. Y. Gauthier, R. Gordon, J. Guay, M. Gresser, S. Kargman, B. Kennedy, Y. Leblanc, S. Leger, J. Mancini, G. P. O'Neil, M. Ouellet, M. D. Percieval, H. Perrier, D. Riendeau, I. Rodger, P. Tagari, M. Therien, P. Vickers, E. Wong, L. J. Xu, R. N. Young, R. Zamboni, S. Boyce, N. Rupniak, M. Forrest, D. Visco and D. Patrick, The discovery of rofecoxib, [MK 966, VIOXX ${ }^{\circledR}$, 4-(4'-methylsulfonylphenyl)-3-phenyl-2(5H)-furanone], an orally active cyclooxy-genase-2 inhibitor, Bioorg. Med. Chem. Lett. 9 (1999) 1773-1778.

7. J. J. Tally, D. L. Brown, J. S. Carter, M. J. Graneto, C. M. Koboldt, J. L. Masferrer, W. E. Perkins, R. S. Rogers, A. F. Shaffer, Y. Y. Zhang, B. S. Zweifel and K. Seibert, 4-[5-Methyl-3-phenylisoxazol-4-yl]-benzenesulfonamide, valdecoxib: A potent and selective inhibitor of COX-2, J. Med. Chem. 43 (2000) 775-777.

8. J. J. Tally, S. R. Bertenshaw, D. L. Brown, J. S. Carter, M. J. Graneto, M. S. Kellogg, C. M. Koboldt, J. Yuan, Y. Y. Zhang and K. Seibert, N-[[(5-Methyl-3-phenylisoxazol-4-yl)-phenyl]sulfonyl]propanamide, sodium salt, parecoxib sodium: A potent and selective inhibitor of COX-2 for parenteral administration, J. Med. Chem. 43 (2000) 1661-1663. 
9. D. Riendeau, M. D. Percieval, C. Brideau, S. Charleson, D. Dube, D. Ethier, J. P. Falgueyret, R. W. Friesen, R. Gordon, G. Greig, J. Guay, J. Mancini, M. Ouellet, E. Wong, L. J. Xu, S. Boyce, D. Visco, Y. Girard, P. Prasit, R. Zamboni, I. W. Rodger, M. Gresser, A. W. Ford-Hutchinson, R. N. Young and C. C. Chan, Etoricoxib (MK-0663): Preclinical profile and comparison with other agents that selectively inhibit cyclooxygenase-2, J. Pharmacol. Exp. Ther. 296 (2001) 558-570.

10. M. R. Yadav, R. Giridhar and H. B. Prajapati, A Process for Preparation of 3-[o-/m-/p-Mono/DisubstitutedPhenyl]-4-[o-/p-Substitutedphenyl]furazans and Furoxans, Indian Patent Appl. No. 109/MUM/ 2004, Feb. 2004.

11. H. Cerecetto and W. Porcal, Pharmacological properties of furoxans and benzofuroxans: Recent developments, Mini-Rev. Med. Chem. 5 (2005) 57-71.

12. V. G. Granik and N. B. Grigor, Nitric oxide synthase inhibitors: Biology and Chemistry, Russ. Chem. Bull. 51 (2002) 1973-1995.

13. C. Velazquez, P. N. P. Rao, R. McDonald and E. E. Knaus, Synthesis and biological evaluation of 3,4-diphenyl-1,2,5-oxadiazole-2-oxides and 3,4-diphenyl-1,2,5-oxadiazoles as potential hybrid COX-2 inhibitor/nitric oxide donor agents, Bioorg. Med. Chem. 13 (2005) 2749-2757.

14. J. S. Buck and W. S. Ide, Mixed benzoins. I, J. Am. Chem. Soc. 52 (1930) 220-224.

15. J. S. Buck and W. S. Ide, Mixed benzoins. II, J. Am. Chem. Soc. 52 (1930) 4107-4109.

16. S. T. Shirude, P. Patel, R. Giridhar and M. R. Yadav, An efficient and time saving microwave assisted selenium dioxide oxidation of 1,2-diarylethanones, Indian. J. Chem. 45B (2006) 1080-1085.

17. H. Sano, T. Noguchi, A. Tanatani, Y. Hashimoto and H. Miyachi, Design and synthesis of subtype-selective cyclooxygenase (COX) inhibitors derived from thalidomide, Bioorg. Med. Chem. 13 (2005) 3079-3091.

18. C. A. Winter, E. A. Risley and G. W. Nuss, Carrageenin-induced edema in hind paw of the rat as an assay for antiinflammatory drugs, Proc. Soc. Exp. Biol. Med. 111 (1962) 544-547.

19. SYBYL Molecular modeling system, version 6.9, Tripos, Inc., St. Louis, USA, 2003.

20. R. A. Friesner, J. L. Banks, R. B. Murphy, T. A. Halgren, J. J. Klicic, D. T. Mainz, M. P. Repasky, E. H. Knoll, M. Shelly, J. K. Perry, D. E. Shaw, P. Francis and P. S. Shenkin, Glide: A new approach for rapid, accurate docking and scoring. 1. Method and assessment of docking accuracy, J. Med. Chem. 47 (2004) 1739-1749.

21. M. Clark, R. D. Crammer and N. van Opdenbosh, Validation of the General-Purpose Tripos 5.2 force field, J. Comput. Chem. 10 (1989) 982-1012.

22. J. H. Boyer, R. F. Reinisch, M. J. Danzig, G. A. Stoner and F. Sahhar, The transformation of $\psi-0-$ dinitroso aromatic compounds into o-nitroaryl amines, J. Am. Chem. Soc. 77 (1955) 5688-5690.

\section{$S A \check{Z} E T A K$}

\section{Istraživanja 3,4-diaril-1,2,5-oksadiazola i njihovih $\mathrm{N}$-oksida: Potraga za boljim COX-2 inhibitorima}

MANGE RAM YADAV, SHRIKANT T. SHIRUDE, DEVENDRA S. PUNTAMBEKAR, PINKAL J. PATEL, HETAL B. PRAJAPATI, ARVIND PARMAR, R. BALARAMAN i RAJANI GIRIDHAR

Sintetizirana je serija 3,4-diaril-1,2,5-oksadiazola i 3,4-diaril-1,2,5-oksadiazol $\mathrm{N}$-oksida i ocijenjena njihova sposobnost vezivanja na COX-2 i COX-1 in vitro i protuupalno djelovanje na edem šape štakora. Spojevi sa $p$-metoksi ( $p$-OMe) supstituentom 9, 21, 34, 41, 42 bolje su inhibirali COX-2 nego ostali spojevi. 3,4-Di(4-metoksifenil)-1,2,5-oksadia- 
zol N-oksid (42) inhibirao je COX-2 za 54\% u koncentraciji od $22 \mu \mathrm{mol} \mathrm{L}-1$, a COX-1 za $44 \%$ u koncentraciji $88 \mu \mathrm{mol} \mathrm{L}^{-1}$, ali je in vivo slabo djelovao protuupalno. Njegov deoksigenirani derivat 21 pokazao je slabiju inhibiciju COX-2 enzima (26\% u koncentraciji $\left.22 \mathrm{mmol} \mathrm{L}^{-1}\right)$ i jaču inhibiciju COX-1 (71\% u koncentraciji $\left.25 \mathrm{mg} \mathrm{kg}^{-1}\right)$, što je bolje od standarda celokoksiba (48\% u koncentraciji 12,5 mg kg-1). Molekularno je modeliranje pokazalo da je metoksi skupina smještena u blizini sekundarnog džepa na enzimu COX-2 i da utječe na vodikove veze interakcija na aktivnom mjestu COX-2. Ova preliminarna istraživanja sugeriraju da bi se u seriji oksadiazol/ $N$-oksida mogao naći predvodni spoj s $p$-metoksi skupinom na benzenskom prstenu.

Ključne riječi: 1,2,5-oksadiazol, 1,2,5-oksadiazol N-oksid, COX-2 inhibitor

Pharmacy Department, Faculty of Technology and Engineering, Kalabhavan, The M. S. University of Baroda, Vadodara-390 001, India 